\title{
Differences in the Characteristics of the Bacterial Community in the Epilithon and River Water as Demonstrated by Plate Counts Using Different Temperatures and Staining Methods
}

\author{
Kazuko Morikawa and Takashi Tonozuka
}

\begin{abstract}
A study was made on seasonal fluctuations in bacterial density in the water column and the benthic epilithon at Koremasa, near the site of the most recent study of the River Tamagawa in Tokyo. Water quality and environmental factors at Koremasa were influenced largely by fluctuations in discharge at the site. Consequently, the amounts of DOC and P-compounds were correlated with the discharge summed for 5 days before the sampling day. Principal component analysis of water quality and environmental factors showed that the first principal component was composed of DOC, $\mathrm{PO}_{4}-\mathrm{P}, \mathrm{TDP}, \mathrm{NH}_{4}-\mathrm{N}, \mathrm{NO}_{3}-\mathrm{N}$ and chlorophyll- $a$ in the epilithon. The bacterial densities in the river water and epilithon were determined by the acridine orange direct count (AODC), INT-formazan count (INT) and agar plate method employing four different incubation temperatures. Changes in bacterial density estimated by plate counts at $20^{\circ} \mathrm{C}$ and $30^{\circ} \mathrm{C}$ in the epilithon were highly correlated with the first principal component. The percentage of the INT/AODC was higher in the epilithic microbial community than in the water one. However, bacterial density in the river water was controlled different factors investigated in this study. Thus, the bacteria on the upper surface of the benthic pebbles constitute an autochthonous community. Most of those in the water column may be allochthonous species flowing in the water.
\end{abstract}

Key words : epilithic bacterial community, River Tamagawa, incubation temperature, INT-formazan counts

\section{Introduction}

In the upper part of the River Tamagawa, the density of benthic epilithic bacteria estimated by plate counts has been shown to fluctuate with the change in amount of chlorophyll in the epilithic microbial community (MoRIKawa, 1984). Moreover, the generic composition of bacteria in the epilithon is also influenced by the amount of the chlorophyll in the epilithon (Morikawa, 1987). However, in the middle part of the R. Tamagawa, changes in bacterial density in the epilithon enumerated by acridine orange direct counts corresponded to fluctua. tions in the amounts of DOC and phosphorus compounds (MoRIKawa, 1993). The difference between the factors influencing the bacterial communities of the two components of the river may be due to differences in water quality, discharge and structure of the riverbed. In this study, factors controlling bacterial density in the river water and epilithon were investigated using the agar plate method employing four different incubation temperatures and two kinds of staining techniques, and then differences in the characteristics of the bacterial community in the epilithon and river water were considered.

\section{Materials and methods}

\section{2-1. Study site}

The study site was situated $100 \mathrm{~m}$ downstream of the site investigated in the most recent previous study (MORIKAwA, 1993). Compared to the site investigated previously, the water velocity at the study site was slightly 
high throughout the year, but it was not divided into current flows.

\section{2-2. Method of measurement}

River water was sampled directly from $5 \mathrm{~cm}$ below the surface using a sterilized polyethylene bottle. The epilithic bacterial community on each pebble was sampled as described previously (Morikawa, 1984). Suspensions of the epilithon from each pebble were dispersed by aseptic sonication in ice-cooled water. Subsamples $(10$ or $20 \mathrm{ml})$ of the suspension were then filtered through a glass-fiber filter (Whatman $\mathrm{GF} / \mathrm{C}$ ), and dry weight, ignition loss, chlorophyll $a$ (Chl. $a$ ) and phaeophytin $a$ (Phae. a) were determined. Measured parameters of the river water were temperature, $\mathrm{pH}$, dissolved oxygen (DO), biochemical oxygen demand (BOD), chemical oxygen demand (COD), $\mathrm{NO}_{3}$ $-\mathrm{N}, \mathrm{NO}_{2}-\mathrm{N}$, total dissolved phosphorus (TDP), $\mathrm{PO}_{4}-\mathrm{P}$ (RP) and Chl. $a+$ Phae. $a$. DO was expressed as concentration and percentage saturation (DO\%). Details of these analytical methods were given previously (Morikawa, 1984). Values for discharge at Koremasa and principal component analysis were obtained by the methods described previously (MoriKawa, 1993).

\section{2-3. Enumeration of bacteria}

Aerobic heterotrophic bacteria from the epilithon and river water were enumerated by the spread plate method. A $0.1-\mathrm{ml}$ aliquot of each successive dilution $\left(10^{-1}\right)$ of the sonicated suspension or the river water was spread onto the surface of twelve different plates with $1 / 2$ PYG agar medium. The twelve inoculated plates were divided into four groups, and then one set of three incubated at each of $5,20,30$ and $37^{\circ} \mathrm{C}$ until no further colonies developed on any of the plates. The numbers of colonies on the agar plates were then counted and the results for bacterial density were expressed as colony-forming units (CFU). The total number of bacteria from the epilithon and the river water were determined by acridine orange epifluorescence direct counts (AODC) (HoBBIE et al., 1977). The red and green particles on the filter were counted under an epifluorescence microscope (Olympus BHS-RFK). Observa- tions were made with a blue excitation filter (BP 490) and supplementary absorbing filter (O 530 ), but without a supplementary excitation filter (EY 455). The sonicated suspension of epilithon or the river water was put into sterile, particulate-free 10-ml amber glass bottles. The samples were amended with $1 \mathrm{ml}$ of $0.2 \%$ 2 -( $p$-indophenyl)- 3 -( $p$ - nitrophenyl)- 5 - phenyltetrazolium chloride (INT), following the method of TABOR et al. (1982). The sample was then incubated for $30 \mathrm{~min}$ at the in situ temperature with shaking to permit the formation of INT-formazan red-black particles, and fixed with $0.5 \mathrm{ml}$ glutaraldehyde solution (20\%). Then the INT-amended sample was stained with $\mathrm{AO}$ using the method described above. The stained sample was then filtered through an irgalan black-stained filter $(0.2 \mu \mathrm{m}$ Nuclepore). The INT-formazan particles were enumerated under the microscope, and in the same microscopic field the AO-stained particles were counted using epifluorescence microscopy. Where two particles were observed in the microscopic field, they were determined as INT-positive bacteria (INT counts).

\section{Results and discussion}

\section{3-1. Seasonal changes in environmental factors}

The pattern of fluctuation of the discharge between Feb. 1988 and Feb. 1989 was broadly similar to that between Dec. 1985 and Feb. 1987 described previously (Morikawa, 1993). Normal discharge was $30 \mathrm{~m}^{3} \cdot \mathrm{s}^{-1}$ and very high values were observed in August and September. Seasonal fluctuations in environmental factors at Koremasa in Feb. 1988 to Feb. 1989 are shown in Figure 1 and Figure 2. Water temperature showed an obvious seasonal change. The highest value was $21.9^{\circ} \mathrm{C}$, the lowest value was $9.1^{\circ} \mathrm{C}$ and the mean was $16.8^{\circ} \mathrm{C}$. Fluctuations in $\mathrm{pH}$ were minor, the values being alkaline at about $\mathrm{pH} 8$ throughout the period. DO\% was saturated in summer, but undersaturated in winter. In contrast, the BOD and DOC were low in summer and high in winter; in summer DOC was low, as in oligotrophic regions. The pattern of change in $\mathrm{NH}_{4}-\mathrm{N}$ resembled that in DOC; Chl. 


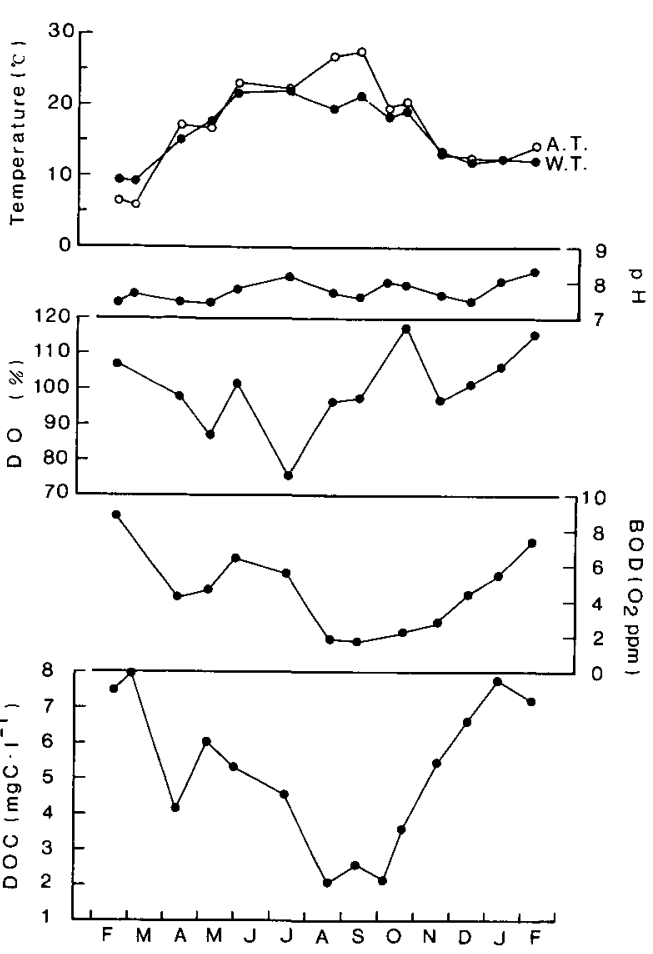

Fig. 1. Seasonal fluctuations in air temperature (A. T.), water temperature (W. T.), $\mathrm{pH}$, dissolved oxygen (DO), BOD, DOC in the River Tamagawa at Koremasa during Feb. 1988 to Feb. 1989.

$a+$ Phae. $a$ showed the highest value in May, when Phae. $a$ constituted a large part of the total. In the case of the epilithon, the dry weight ranged between 2.00 and $29.0 \mathrm{mg} \cdot \mathrm{cm}^{-2}$, with a mean of $7.81 \mathrm{mg} \cdot \mathrm{cm}^{-2}$. Ignition loss of the epilithon ranged between 0.56 and $5.12 \mathrm{mg}$. $\mathrm{cm}^{-2}$, with a mean of $1.56 \mathrm{mg} \cdot \mathrm{cm}^{-2}$. Chl. $a+$ Phae. $a$ ranged between 2.75 and $50.1 \mu \mathrm{g} \cdot \mathrm{cm}^{-2}$, with a mean of $15.1 \mu \mathrm{g} \cdot \mathrm{cm}^{-2}$. It was shown in the most recent study of a site near the present one (Dec. 1985 to Jan. 1987 : MorikaWA, 1993) that water quality was highly correlated with discharge summed for 10 days before the sampling day. In particular, phosphorus compounds represented by TDP or RP were largely affected by the change in discharge summed for 10 days before sampling. The results obtained in the present study agree with this previous report. It was very surprising that similar results were obtained for different two-year periods, in spite of the vigorous flow and unsta-

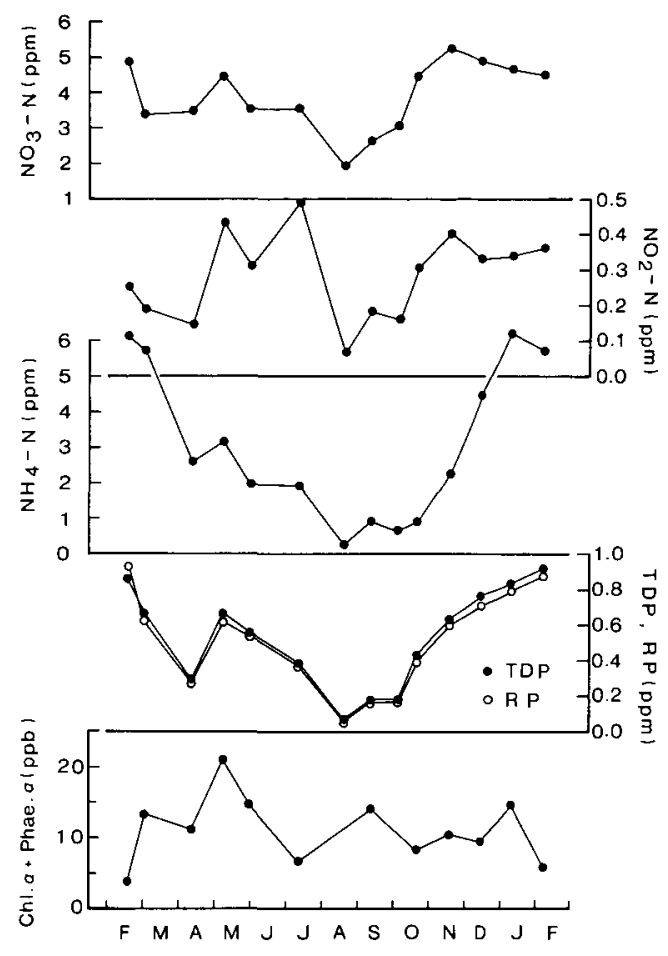

Fig. 2. Seasonal fluctuations in $\mathrm{NO}_{3}-\mathrm{N}, \mathrm{NO}_{2}-\mathrm{N}$, $\mathrm{NH}_{4}-\mathrm{N}, \operatorname{TDP}(\mathrm{O}), \mathrm{RP}(\mathrm{O})$ and Chl. $a+$ Phae. $a$ in River Tamagawa water at Koremasa during Feb. 1988 to Feb. 1989.

ble environment in the river ecosystem. The ignition loss showed a high correlation coefficient $(-0.843, \mathrm{p}<0.001)$ with the discharge on the sampling day. However, the values of DOC $(-0.771, \mathrm{p}<0.001)$, TDP $(-0.763, \mathrm{p}<0.001)$ and $\mathrm{RP}(-0.748, \mathrm{p}<0.001)$ were influenced especially by the discharge summed for 5 days before the sampling day. The minor change in the current velocity may explain the slightly different results on the summed days between the two studies. The environmental factors examined at Koremasa were analyzed by principal component analysis (YANAi et al., 1986). Three components were drawn from this analysis. The first principal component was composed of DOC, $\mathrm{PO}_{4}-\mathrm{P}, \mathrm{TDP}, \mathrm{NH}_{4}-\mathrm{N}, \mathrm{NO}_{3}-\mathrm{N}, \mathrm{Chl} . a$ in the epilithon and discharge over 5 days with correlation coefficients of $0.924,0.950,0.936$, $0.873,0.784,0.887$, and 0.824 , respectively. These factors are those which may be expected to favor the growth of heterotrophic bacteria. 
The second principal component was correlated with DO (ppm) and the third component with $\mathrm{NO}_{2}-\mathrm{N}$, showing correlation coefficients of 0.836 and 0.772 , respectively.

\section{3-2. Bacterial density in the water column}

Figure 3 shows the changes in bacterial density in the water column. Plate counts at the four different incubation temperatures fluctuated around $10^{5} \mathrm{CFU} \cdot \mathrm{cm}^{-3}$, with the $1 / 2 \mathrm{PYG}$ agar plates at $20^{\circ} \mathrm{C}$ showing the highest number of colonies throughout the study and those at $30^{\circ} \mathrm{C}$ the next highest. These two values were correlated with each other throughout, apart from a few obtained in winter on plates incubated at $30^{\circ} \mathrm{C}$. The number of colonies obtained from the plates at $37^{\circ} \mathrm{C}$ showed high density from late summer to fall and the lowest value in winter. Plates incubated at $5{ }^{\circ} \mathrm{C}$ showed the lowest values in the fall, but increased again in winter, with a value higher than the $37^{\circ} \mathrm{C}$ plates. With respect to these two incubation tempera-

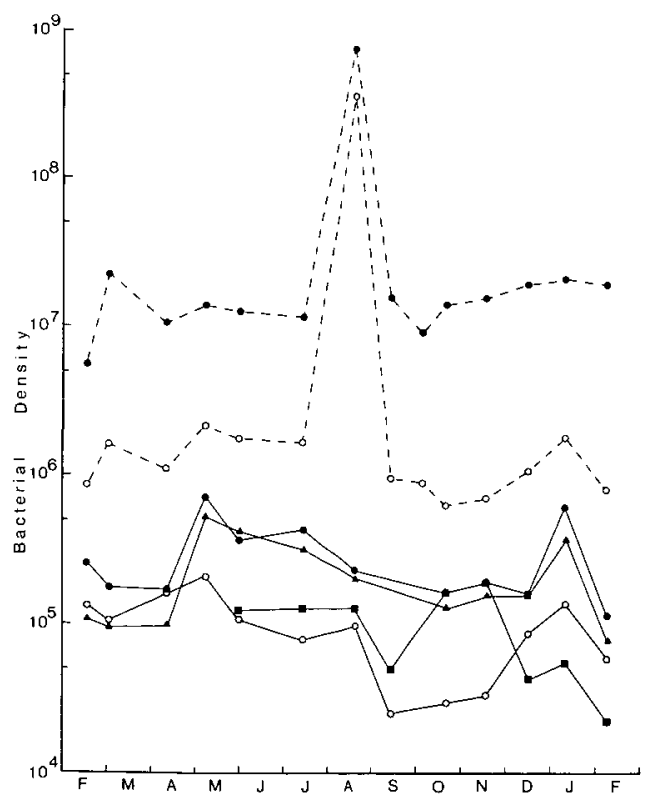

Fig. 3. Seasonal fluctuations in the bacterial density in River Tamagawa water at Koremasa during Feb. 1988 to Feb. 1989.

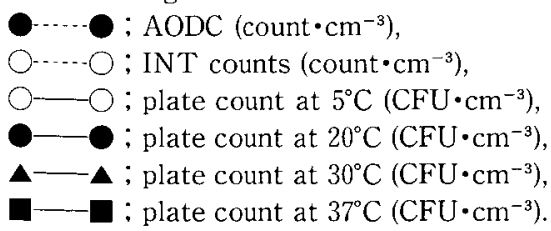

tures, the number of colonies on plates at $37^{\circ} \mathrm{C}$ and the number at $5^{\circ} \mathrm{C}$ corresponded to delays in seasonal changes in water temperature. The bacterial density in the water observed as the AODC gave values of $10^{7}$ counts $\mathrm{cm}^{-3}$ throughout the investigation period, apart from a value of $10^{9}$ counts $\cdot \mathrm{cm}^{-3}$ for the 19 August sample, just after a large flood. This was in marked contrast to normal samples. The density measured by AODC was two orders of magnitude higher than that obtained usually from plate counts, but the order of the AODC counts was equal to that obtained in the most recent study. The INT counts were in the region of $10^{6} \cdot \mathrm{cm}^{-3}$, values in the midrange between those for plate counts and those for AODC. As with the AODC, the INT counts showed a very high value of $10^{9}$ cells $\mathrm{cm}^{-3}$ on 19 August, just after the large flood. Very small particles were evident in the microscope field in this sample; these particles did not show the typical red-black color of INT-formazan, and seemed to be a pale blueblack color. Although it was not clear whether that the pale blue-black particles were true bacteria, they were added to the AODC and INT counts because there was no clear reason for excluding them as bacterial cells. This is the next problem to be clarified.

\section{3-3. Changes in bacterial density in ben- thic epilithon}

Changes in bacterial density in the benthic epilithon are shown in Figure 4. In the case of the $1 / 2$ PYG agar plates incubated at four different temperatures, the highest number of colonies was found on plates at $20^{\circ} \mathrm{C}$. As with changes in the water column, changes in density in the epilithon showed similar patterns at $20^{\circ} \mathrm{C}$ and $30^{\circ} \mathrm{C}$. In Figure 2, however, the two lines showing changes at $20^{\circ} \mathrm{C}$ and $30^{\circ} \mathrm{C}$ crossed everywhere. Moreover, the changes in density on the $5^{\circ} \mathrm{C}$ plates resembled those at $20^{\circ} \mathrm{C}$ and $30^{\circ} \mathrm{C}$, with values showing almost the same order of magnitude as those at $20^{\circ} \mathrm{C}$ and $30^{\circ} \mathrm{C}$. The density on the $37^{\circ} \mathrm{C}$ plate was lower than that at any of the other incubation temperatures throughout the study, except in October. In contrast to the bacterial community in the water column, fluctuations in the AODC and 
INT counts in the epilithon were very slight. Fluctuation patterns of the AODC and INT

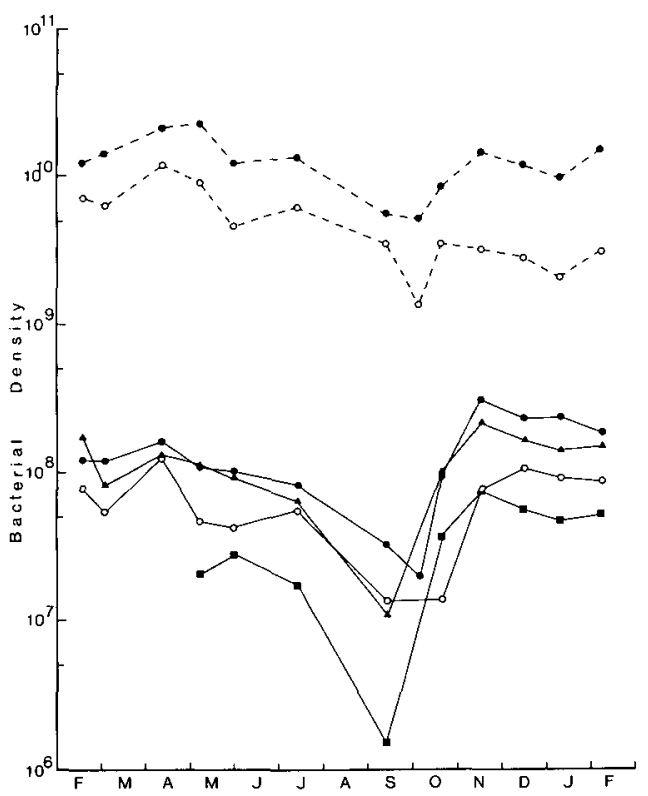

Fig. 4. Seasonal fluctuations in the bacterial density in epilithon on benthic pebbles in the River Tamagawa at Koremasa during Feb. 1988 to Feb. 1989.

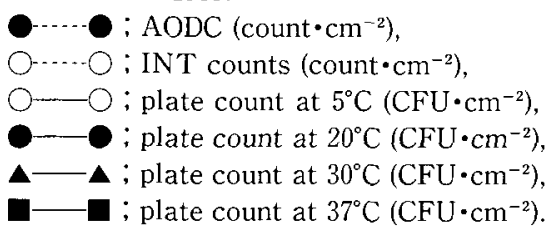

counts showed changes differing from those on the plates. It was interesting that the ratio of the INT to the AODC count was higher in the epilithon bacterial community than in the river water bacterial community, since the number of INT-positive bacteria usually corresponds to live bacteria having respiratory ability. The high ratios of INT to AODC counts reflected the presence of the large number of live bacteria in the epilithon community.

Table 1 shows the correlation coefficient $(\mathrm{P}<$ 0.001 ) between environmental factors and bacterial density in the epilithon. The bacterial density enumerated by plate counts showed a high correlation with the first principal component, especially the counts obtained at $20^{\circ} \mathrm{C}$ and $30^{\circ} \mathrm{C}$. It seems clear that the bacterial community enumerated by agar plate counting had responded to organic substances like DOC and phosphorus compounds and could increase using these materials. On the other hand, AODC and INT counts did not show a significant correlation with any of the factors examined, unlike the results of the most recent previous study. The difference in the results was due to the counting method used for AODC and the environmental conditions themselves. In contrast to the most recent previous study, the AODC was obtained using epifluorescence

Table 1. Correlation coefficients between environmental factors and number of bacteria in River Tamagawa epilithon at Koremasa during Feb. 1988 to Feb. 1989. (* $: \mathrm{p}<0.001, \cdot: \mathrm{p}<0.01)$.

\begin{tabular}{|c|c|c|c|c|c|c|c|}
\hline & & \multicolumn{6}{|c|}{ The number of bacteria in epilithon } \\
\hline & & \multirow[t]{2}{*}{ AODC } & \multirow{2}{*}{$\begin{array}{l}\text { INT } \\
\text { count }\end{array}$} & \multicolumn{4}{|c|}{ Plate count } \\
\hline & & & & $5^{\circ} \mathrm{C}$ & $20^{\circ} \mathrm{C}$ & $30^{\circ} \mathrm{C}$ & $37^{\circ} \mathrm{C}$ \\
\hline \multicolumn{2}{|l|}{$\mathrm{NO}_{3}-\mathrm{N}$} & 0.546 & 0.259 & 0.521 & $0.713 \cdot$ & $0.795^{*}$ & $0.903^{*}$ \\
\hline \multicolumn{2}{|l|}{ Discharge } & -0.315 & -0.093 & -0.594 & $-0.773^{*}$ & $-0.864^{*}$ & $-0.940^{*}$ \\
\hline \multicolumn{2}{|c|}{ Discharge summed for 5 days } & -0.338 & -0.177 & -0.570 & $-0.867^{*}$ & $-0.846^{*}$ & $-0.937^{*}$ \\
\hline \multicolumn{2}{|c|}{ Discharge summed fom 10 days } & -0.343 & -0.321 & -0.689 • & $-0.823^{*}$ & $-0.872^{*}$ & $-0.936^{*}$ \\
\hline \multicolumn{2}{|c|}{ 1st principal component } & 0.305 & 0.094 & $0.699 \bullet$ & $0.769^{*}$ & $0.789^{*}$ & $0.840^{\circ}$ \\
\hline \multirow{6}{*}{$\begin{array}{l}\text { Bacterial number } \\
\text { in river water }\end{array}$} & AODC & $0.660^{\circ}$ & 0.464 & 0.232 & 0.229 & -0.016 & 0.313 \\
\hline & INT count & 0.513 & 0.511 & 0.277 & 0.039 & -0.142 & -0.119 \\
\hline & $5^{\circ} \mathrm{C}$ plate & -0.003 & 0.005 & 0.430 & 0.244 & 0.329 & 0.310 \\
\hline & $20^{\circ} \mathrm{C}$ plate & -0.566 & -0.452 & -0.313 & -0.311 & -0.354 & -0.595 \\
\hline & $30^{\circ} \mathrm{C}$ plate & -0.539 & -0.486 & -0.380 & -0.294 & -0.376 & -0.628 \\
\hline & $37^{\circ} \mathrm{C}$ plate & -0.010 & 0.472 & -0.601 & -0.405 & -0.335 & -0.356 \\
\hline
\end{tabular}


microscopy without supplementary excitation filter (EY 455) for the blue excitation filter. When the supplementary excitation filter was used during observation of AODC, the ultramicro particles disappeared, and the number of particles observed decreased to about $36.5 \%$ (520.0 to 189.6). These fine particles were observed only in the samples of the epilithon bacterial community. Moreover, the order of the AODC counts was one order of magnitude higher than that obtained in the recent study. Thus the present results may have included particles other than bacteria. In the ocean ecosystem it has been reported that many virus particles shown by DNA staining exist with the bacterial community (BERGE, et al., 1989 ; HARA, et al., 1991). It was therefore not surprising that many virus-like particles existed in the river epilithon bacterial community. The nature of these small particles is the next prob lem to be addressed.

Table 2 shows the correlation coefficient between environmental factors showing significant correlation with bacterial density in the river water. The densities enumerated by AODC and INT counts were correlated with the discharge on the sampling day and with that accumulated during the 5 days before sampling. This may have been due to the large number of particles caused by the large flood in August. Only the density enumerated by the plate counts at $30^{\circ} \mathrm{C}$ was correlated with the $2 \mathrm{nd}$ principal component. In both the epilithon and the river water bacterial community, the highest number of colonies was obtained from the plate incubated at $20^{\circ} \mathrm{C}$. The water temperature changed from season to season, and so the bacterial community would be expected to change accordingly. Sieburth (1967) and Trentham et al. (1981) observed that fluctuations in bacterial density in an estuarine bacterial community were delayed by two months in relation to changes in water temperature. In the present study changes in bacterial density in the water column shown by incubation at $37^{\circ} \mathrm{C}$ were delayed slightly with respect to changes in water temperature during October and November. However, the epilithic bacterial community did not show such a delayed pattern of fluctuation. Since the response to the high incubation temperature was observed only in the planktonic bacterial community, the bacterial group obtained at $37^{\circ} \mathrm{C}$ was not an indication of delayed adaptation, but possible contamination with organisms having a high optimum temperature such as Enterobacteriaceae. These bacteria could not settle into the epilithon to become part of that typical bacterial community. In contrast, the bacterial density shown by incubation at $5^{\circ} \mathrm{C}$ was high when the water temperature was low, both in the epilithic and planktonic communities. Their increase was delayed in relation to the change in the low water temperature, and thus these bacterial groups may be adapted to low water temperature. The plate count method might explain the changes in the composition of aerobic heterotrophic bacteria having the ability to divide and increase in the river ecosystem.

\section{Conclusion}

The present results show that the bacterial communities in the benthic epilithon and in the water column are controlled by different en-

Table 2. Correlation coefficients between environmental factors and number of bacteria in River Tamagawa water at Koremasa during Feb. 1988 to Feb. 1989. (*: $\mathrm{p}<0.001, \cdot: \mathrm{p}<0.01)$.

\begin{tabular}{lrrrrrrr}
\hline & \multicolumn{5}{c}{ The number of bacteria in river water } \\
& AODC & INT & \multicolumn{4}{c}{ Plate count } \\
\cline { 5 - 8 } & & Count & $5^{\circ} \mathrm{C}$ & $20^{\circ} \mathrm{C}$ & $30^{\circ} \mathrm{C}$ & $37^{\circ} \mathrm{C}$ \\
\hline Discharge & $0.847^{*}$ & $0.916^{*}$ & -0.091 & -0.093 & 0.007 & -0.231 \\
Discharge summed for 5 days & 0.697 & $0.751^{*}$ & -0.200 & -0.116 & -0.011 & -0.200 \\
Dry weight & -0.486 & 0.092 & $0.825^{*}$ & 0.360 & 0.214 & -0.312 \\
2nd principal component & 0.244 & -0.008 & -0.415 & $-0.738 \bullet$ & $-0.794^{*}$ & -0.617 \\
\hline
\end{tabular}


vironmental factors. The fact that the bacterial community in the epilithon fluctuated with the first principal component and had a high ratio of INT to AODC counts suggests that the bacteria on the upper surface of the benthic pebbles constitute an autochthonous community in the river ecosystem. Most of the bacterial com. munity in the water column may be alloch thonous species flowing in the water.

\section{Acknowledgement}

We are grateful to Dr. Norio OGURA and the staff of the Laboratory of Science of Soil and Aquatic Environment, Tokyo University of Agriculture and Technology. Thanks are also extended to Hiroo IsHikawa of the Environmental Control Center. This study was supported in part by a Grant-in-Aid (No. 63540514) for Scientific Research from the Ministry of Educa. tion, Science and Culture, Japan.

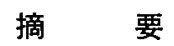

\section{異なる計数方法にもとつく河川水および 河床付着層細菌群集の相違}

多摩川中流域是政において河川水と河床付着層 の細菌群集を, アクリジンオレンジ染色法, INT フォルマザン計数法および 4 段階の培養温度によ る平板法によって計数した。本調查地点に扔ける 水質変動は，前報に述べた前年の結果と等しく， $\mathrm{DOC}$ と P-化合物の変動は調查日から遡って 5 日 間の流量変動と高い相関をもって変動した。調查 地点の環境要因について主成分分析を行った結 果, 前報とほほ同様に, DOC, $\mathrm{PO}_{4}-\mathrm{P}, \mathrm{TDP}, \mathrm{NH}_{4}$ $-\mathrm{N}, \mathrm{NO}_{3}-\mathrm{N}$, 河川水中のクロロフィル量等からな る主成分を得た。平板法による計数值では $20^{\circ} \mathrm{C} に$

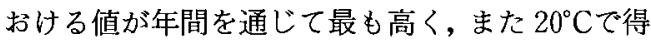
た付着層の細菌は主成分と有意の相関を持って変 動した。また, $5^{\circ} \mathrm{C}$ の培養で得られた付着の細菌数 は, 水温変動に 2 力月遅れて変動した。しかし, 河川水中の細菌数はいずれの測定方法でも環境要 因とは独立に変動した。付着層の細菌群集の変動 が環境要因と呼応して変動したことから，付着層 における細菌群集は河川における自生的な種であ り，河川水を流れて行く細菌群集の多くは他生的 な種であると考えられた。AO 染色法・INT 計数 法による細菌数の変動は，環境要因との関連が認 められなかった。なお,これらの計数の際, 付着
層標本のフィルターには微少粒子が混在していた が，河川水標本には見られなかった。

\section{References}

Bergh, O., K. Y. Borsheim, G. Brantbak and M. Heldal (1989): High abundance of viruses found in aquatic environments. Nature, 340 : $467-468$.

Hara, S., K. Terauchi, and I. Kolke (1991): Abundance of viruses in marine waters: Assessment by epifluorescence and transmission electron microscopy. Appl. Environ. Microbiol,, 57 : 2731-2734.

Hobbie, J. E., R. J. Daleey, and S. Jasper (1977): Use of nuclepore filters for counting bacteria by fluorescence microscopy. Appl. Environ. Microbiol., $33: 1225-1228$

MoriKaWA, K. (1984): Seasonal fluctuation in the number of aerobic heterotrophic bacteria and its relation to environmental factors in the upstream area of the Tamagawa River. Jpn. J. Limnol. $45:$ : 69-78. (in Japanese).

MorIKawa, K. (1987): Characteristics of generic composition of aerobic heterotrophic bacteria in periphyton at an oligotrophic region in the Tamagawa River. Jpn. J. Limnol. 48: 55-65.

Morikawa, K. (1993): Seasonal fluctuation in the number of bacteria and its relation to environmental factors in the middle course of the Tamagawa River. Jpn. J. Limnol., 54: 317 -327. (in Japanese).

Sieburth, J. M. (1967) : Seasonal selection of estuarine bacteria by water temperature. J. exp. mar. Biol. Ecol., 1: 98-121.

TABOR, P. S. and R. A. NeIHOF (1982): Improved method for determination of respiring individual microorganisms in natural waters. Appl. Environ. Microbiol., 43 : 1249-1255.

Trentham, J. N. and T. R. James (1981): Seasonal selection in a freshwater heterotrophic bacterial community. Microb. Ecol. 7 : 323-330.

Yanal, H. and H. TAKagl (ed.) (1986): Handbook of Multivariate Analysis, Gendai Sugaku Co. (in Japanese).

（著者：森川和子・殿塚隆史, 東京農工大学一般教 育部, 干 183 東京都府中市幸町 3-5-8；Kazuko MorIkAWA, Takashi Tonozuka, Laboratory of Biology, Tokyo University of Agriculture and Technology Fuchu, Tokyo 183, Japan)

Received : 26 January 1994 Accepted : 25 May 1994 